\title{
5 \\ The body of thinking and of emotions among the Rotenese
}

\author{
James J. Fox
}

\section{Introduction}

This chapter examines the language of thinking and feeling among the Rotenese of eastern Indonesia. It is divided into two complementary parts. Initially, I focus on the specific terms, idioms and ritual expressions that constitute the linguistic basis for the articulation of thinking and for the social expression of emotions.

Among the Rotenese, thinking and the emotions are intimately located within an 'inner person'. This 'inner person' is distinguished from the social semblance that the person presents to the world. Both the inner self and the semblance it presents are associated with specific parts of the body. One of the chief purposes in this section of the chapter is to explore, in some detail, the use of bodily metaphors in the expression of emotions and of thinking.

In this analysis, I combine an examination of ordinary language usage with ritual language usage. Ritual language as a formal register highlights key modes of thought and emotion. Although these thoughts and emotions are those spoken of in ordinary language, ritual language gives emphasis to their particular qualities and, because of its formal dyadic structure, 
it pairs specific forms of thinking and feeling, often grounding them in metaphoric imagery. This is particularly the case in the ritual admonitions that encourage moral behaviour and insist on proper modes of action.

In the second part of this chapter, I endeavour to locate the use of such metaphors in their social context. Social context is essential to understanding such linguistic usage. This discussion requires the grounding of thought and emotions in notions of the person and in the ideals and values that are given emphasis in Rotenese society. It also requires consideration of the historical development of Rotenese society, where such ideals and values have served as a motivating force for action.

Underlying the expression of the emotions and of thinking among the Rotenese is a specific cultural conception of the person. This conception credits maternal relatives with responsibility for a person's physical being. Through the gift of a woman, wife-givers become life-givers. In the Rotenese botanic idiom, they are regarded as 'planting' (sele) progeny among their wife-takers. These children are explicitly described as 'plants' (sele-dadi). A specific ritual relationship is established between the 'mother's brother of origin' (or 'trunk mother's brother': to'o-huk) and the 'plants', his sister's children, whom he tends throughout their life. All the rituals of the life cycle, which he directs, are concerned with promoting the vitality of the physical person and eventually conclude with the rituals of burial and the dispatch of that person. The mother's brother of origin is duly acknowledged and compensated for his ministration to the physical person to the extent that, were a person to accidentally injure himself by drawing blood, the 'mother's brother of origin' would demand compensation for the injury. This relationship continues for another generation. The 'grandfather of origin' (ba'i-huk) retains specific ritual rights over the children of his sister's children. ${ }^{1}$

1 I have discussed these ideas, the idioms that give expression to them and social consequences of these ideas in a long paper entitled 'Sister's child as plant: Metaphors in an idiom of consanguinity' (Fox 1971: 219-52). 


\section{The distinction between 'inside' (dalek) and 'outside' (de'ak)}

A Rotenese will often preface a well-considered opinion with the remark that it comes from 'within' (neme dale-na) or offer a reflection that has been 'pondered within' (afi nai dalek). Such comments are to be taken seriously because they are purposely distinguished from the ordinary, but almost continuous, flow of talk that characterises Rotenese social life.

To converse, dispute, countercomment and qualify another's statement are what give pleasure to social engagement. These diverse sorts of speaking are all classified as dede'ak, based on the reduplicated form of the root term, de'ak, meaning 'outside'. Such 'out-outside talk' (if one were to translate dedeak literally) is regarded as a less serious form of speaking, expressed as enjoyment in the art of speaking and in response to a present but passing occasion. Dedeak can also be applied in disputes where the arguments may be as diverse and various as the situation allows. To be able to speak cleverly and manipulatively is highly valued and is cultivated as the face of the social person.

In this flood of talk and argument, the distinction is made between what comes from 'within' and what is for show to the 'outside'. Much of everyday life is about this show-a steady verbal performance that need not come from the heart. One of the common narrative devices in Rotenese folktales - and in many of the histories as well, which take the form of 'trickster tales'-hinges on being told what an ancestral character is thinking, feeling or planning 'within' and what that same character says or does to disguise their intended stratagem.

This dichotomy between 'inside' (dalek) and 'outside' (de'ak) is fundamental and is applied widely in Rotenese classification. Thus, for example, this dichotomy is used to distinguish 'ancestral spirits' (nitu dale: 'inside spirits') from all other varieties of generally malevolent spirits (nitu de'ak: 'outside spirits') (Fox 1971). Similarly, the house, which, according to Rotenese, has a structure analogous to the human body, is divided into an outside portion (uma de'ak: 'outer house'), which can be made accessible to visitors, and an inner sanctum (uma dalek: 'inside house'), which contains the hearth and access to the loft—a place open only to the inner family, where the harvest is stored, where healing occurs and where the ancestors can be approached. I once asked an elder who still 
sacrificed to the ancestors about this part of the house. His reply was that no one knows what anyone does in their inner house; the inside is closed to outside scrutiny.

Similarly, a person's identity is associated with a person's name (nade), but a 'name' is itself divided into an inner aspect and an outer aspect. The inner aspect is one's 'hard name' (nade balakaik). This hard name is one's ancestral name. It links a person to a succession of ancestors whose names are shared most closely among lineal relatives. These names do not 'descend' but rather 'ascend' from a 'trunk' ancestor $(h u k)$. The model is that of a tree; the term balakaik is an adjective most often used to describe the hard inner core of a tree.

Hard names have two parts, the second of which is the name that 'ascends' from the trunk. The first part of the name is one part of the hard name of a close relative (not necessarily a lineal relative) to whom the newborn child is believed to have some intimate connection. This second component of a person's name is called the tamok name and it may occur-indeed, it often occurs - that contemporaries of roughly the same age may share a connection by name to the same tamok relative. In this case, there exists a living connection between them.

A person's hard name should never be spoken or uttered outside a ritual context. To speak the hard name is not just to identify the person, but also to invoke a person's ancestral core. Instead, there exist various means for according a person a 'soft name' (nade manganauk)—an everyday designation that can change as the circumstances of life change. The possibilities are considerable. Teknonyms are one such possibility; another possibility is a soft name that links a person to the placename of prominence or to some unusual event; yet another possibility are names that hint at the tamok name of a person. In one instance, a person I knew well in Termanu was called by the teknonym that was used by his tamok ancestor at the time of his death. As a result, he became known as the 'grandfather' of his older brother.

This distinction between 'hard' and 'soft' names parallels the distinction between 'inside' (dalek) and 'outside' (de'ak). The innermost part of a person is that person's hard name. 


\section{The 'inside' (dalek) as source of the emotions}

In numerous ordinary language contexts, the term $\operatorname{dale}(k)$ refers to a specific inner part of the human person-a physical component of the body that can be associated with 'inner core' or 'heart'. (For translation purposes, in English, the term 'heart' serves better than 'inner core', but it must be realised this gloss is at best an appropriate approximation of the Rotenese term.) As a source of thinking and feeling, the 'heart' $($ dale $(k))$ is the primary locus of numerous expressions that define particular emotional states and basic human qualities. Thus, for example, a good person may be referred to as having 'a good heart' (dale malole); a gentle person has a 'soft heart' (dale mangana'uk); someone who is open and socially engaged is said to have 'a broad heart' (dale maloak); someone who is sad or distressed is said to be 'sick at heart' (dale hedi); a caring person has a 'loving heart' (dale suelsusue); someone who is satisfied or feels fulfilled has his or her 'heart full' (dale ketemak). When people agree with one another, they are 'of one heart' (dale esak). ${ }^{2}$

Among the older generation of Rotenese, there is no indication of an idea of romantic love. Sue, which is the Rotenese term that most closely approximates the notion of 'love', is a complex, wideranging emotion that embraces notions of 'care' and 'sympathy' - a willingness to share in other' feelings, sentiments and suffering. While sue may be used, for example, to describe a mother's love for her child or a brother's love for his sister, sue is preeminently a social emotion of empathy that extends well beyond the family. In ritual language, sue is combined with the verb lai. Relying on a play on words, Rotenese compare the qualities of sue//lai to the seeming care that swarming fish show for each other. Such fish never appear alone but always in close and intimate contact with one another.

2 The Indonesian translation for many (though not all) of these expressions involves a simple substitution of hati ('liver') for dale( $k$ ), thus: dale malole: hati baik; dale maloak: hati terbuka; dale hedi: sakit hati. 
A common expression based on dalel/tei is the phrase dale sue ma tei lai or, more emphatically, in its reduplicated form, dale susue ma tei lalai. This phrase covers a wide gambit of emotions involving 'love and affection' and is often used to express 'sympathy' and indeed 'empathy' as well as 'sorrow' in a time of mourning. ${ }^{3}$

Sadness and anger are also matters of the heart. Instead of necessarily personalising either sadness or anger, these emotions can be idiomatically attributed to the 'heart': dale nama-hoko is 'the heart is happy' (but also, in other contexts, 'the heart has sympathy'); another expression for being 'happy, joyful' is the verb nata-dale, 'to be particularly happy'. By contrast, someone whose 'heart' is continually inclined to be angry is dale nasameluk ('bitter-hearted'). Someone who is envious or jealous literally 'places or sequesters the heart' (napeda dalek), while someone who covets another's possessions is dale-salak ('false-hearted').

Ritual admonitions are cultural assertions on what to do and what not to do. These admonitions occur within long ritual recitations, but, by their nature and format, they are often excerpted from such contexts and used to make moral assertions in ordinary discourse. Many of these admonitions are recognisable by their format: 'Do not ... and do not' (Boso ... ma boso). In ritual language, dale $(k)$ forms a canonical pair with tei $(k)$, a term that refers to 'the stomach, womb, innards'. These two terms are a set pair and form the basis for many dyadic expressions. One of the most common of these expressions that occurs frequently as a ritual admonition is the phrase boso madalek dua ma boso matei telu. Translated literally, it means 'do not have two hearts and do not have three stomachs'. Although this phrase can take on various contextual meanings, its message is to not be of 'two minds'- do not be hesitant, fickle, reluctant, wavering or uncertain. In most contexts, this admonition is used to urge someone to carry out their social obligations without hesitation.

3 One of the characteristic features of Rotenese discourse is that it regularly draws on and alludes to well-known ritual sayings. These sayings are taken from traditional ritual narratives associated with different 'chant characters' who embody various moral qualities. In one such narrative, for example, the dual name Sio Meda ma Lepa Lifu occurs in reference to a friend and companion, who is described as a sio sena ma tio falu ('a nine-fold friend and eight-fold companion'). Love and affection for this companion evoke the phrase dale sue Sio Meda ma tei lai Lepa Lifu ('the love of Sio Meda and the affection of Lepa Lifu'). This association is enough to link the emotion of affection to this particular chant character, whose name serves as a common literary evocation. 
Another common dual expression is tesa tei ma tama dale, which evokes a sought-after state of 'peace and tranquillity'-a sense of contentment and satisfaction and release from anxiety and worry. In ritual contexts, the sense of wellbeing that these terms imply is achieved only in the close company of lineage mates and companions. Hence it denotes a sense of personal peacefulness in a social milieu.

Yet another such dual expression is that for 'sadness and distress': dale hedi ma tei susa. Literally, this phrase translates as being 'sick at heart and troubled in the stomach', but it, too, covers a range of emotions of personal sadness, loss and disappointment.

A further expression is dale hi ma tei nauk, which, roughly translated, means 'heart's desire and stomach's wish'. It refers to being 'self-centred' and 'selfish'. Yet another expression is sale dale ma tuke tei. The literal translation of this phrase is 'misdirection of the heart and regret/sourness of the stomach'. This phrase refers to emotions of 'regret', 'frustration' and 'disappointment' and has been taken up, in Christian rituals, to refer to notions of 'repentance'. A similar dyadic expression that carries much the same import, but without invoking 'heart and stomach' but instead that of 'rock and tree', is ai sale ma batu tuke. Its literal translation is 'tree's misdirection and rock's regret'.

Similarly, the 'heart' is the locus of thought. The idiom dale dudu'a ma a'afina is a typical comment that translates as 'according to [my] heart's thoughts and reflections'. The expression is often used as a preface to what purports to be a considered opinion. Another set of verbs used to express serious thought is the reduplicated pair: dodo ma ndanda. These verbs may best be translated as 'to consider and to ponder' and are often combined with adverbial expressions that enforce their seriousness: dodo doak lon ma ndanda sota lon ('to consider for a long time and to ponder deeply'). This pair is one of the most frequently used expressions in describing serious planning or judgement. Formerly, they were the verbs used to describe the assessment process in divination, but they can be used in all sorts of deliberations that require forethought or careful study.

The head and brain are implicated in a person's capacity for thought. A stupid person is said to have a 'hard[-wood] brain' (dodole matea), while someone who is clever and quick in understanding has a dodole dauk ('light/easy brain'). Someone who is stubborn and, by implication, stupid has a 'rock head' (langa batu). 
Each of these expressions has a focus, but together they embrace a spectrum of related emotions: reluctance and hesitancy, inner peace, love, sympathy and sorrow, sadness and distress, selfishness, regret, consideration, deliberation and memory.

\section{Mata as the bodily locus for the outward expression of emotions}

The term mata, in various contexts, carries multiple meanings: 'eye', 'source', 'focus', 'countenance' or 'expression'. ${ }^{4}$ In reference to individuals-whether specifically to the 'eyes' (mata) or, more generally, to the countenance (mata dalek) — mata are where Rotenese see manifest particular qualities of the person. Thus, for example, a pretty face has pleasing eyes (mata mana'a); an ugly face shows 'rubbish, lowly eyes' (mata mangala'uk). A good person is spoken of as having 'good eyes/face' (mata lolek); a person who is reliable has 'straightforward eyes/face' (mata ndos).

More interestingly, an individual can be described positively as having 'shame eyes' (mata mae), meaning that person is respectable and knows how to behave. More often, this expression is used in the negative as a criticism for someone who knows no shame (mata mae ta). The terms, temal/ tetu are frequently used as a contrastive pair: tema implies 'fullness' and 'integrity' while tetu implies 'order' and 'erectness'. In Rotenese, a virgin girl is a mata tema, while the equivalent for a young boy is mata tetu. The Dutch, as outsiders, were originally viewed with suspicion and were described as having 'cat eyes' (mata meok). This expression is less used at present. In terms of facial appearance, 'doubt' is shown on the forehead (dedeik) and 'anger' in the tightening of the neck (boto-lik).

Among the most revealing of ritual admonitions are those that offer counsel on shame and fear, doubt and anger. A common admonition during formal visits between houses - for example, in the case of marriage negotiations - is addressed by the household head to his guests before they enter the house: boso bi ma boso mae ('do not be afraid and do not be ashamed'). Here the emotions of fear and shame are directly and explicitly linked. Another common admonition is boso ma-oda dedeik do manasa boto-lik ('do not show a frown on your forehead or do not show anger in your neck'). Here, 'doubt' is explicitly linked with 'anger'.

4 Robert Barnes's 'Mata in Austronesia' (1977) examines the range of uses of mata among Austronesian languages. 
Anger is a complex emotion. The paired expression for anger in Rotenese is namanasa ma nggenggele. Nama-nasa ('to become angry') requires a verb stem for 'becoming'; it is not a static condition but a process. The verb nggele, or its reduplicated form, nggenggele, combines notions of shrieking and forced violence. Anger is explicitly likened to a 'storm' that arises in the person. Although it sweeps over a person, it is not specifically located within the heart (dalek). On Rote, the control of physical anger is essential in social contexts, especially when talk becomes aggressive. A repeated admonition is: Boso mama-nasa maboso nggenggele ('Do not grow angry and do not grow furious').

Fear is another powerful emotion. Fear (bi) and shame (mae) are linked, but fear has other associations. The feeling of being terrified is associated with a feeling of cold (lini): momou ma malini ('to be cold with fear'). Normally, the term lini ('cool') describes a positive state of personal tranquillity and ritual neutrality. Rituals_including, in particular, the chanting and oratory that accompany them-are intended to produce a condition of 'heat'. When they achieve this state, these rituals are said to 'boil':

Sio laka-doto: 'The feasts of nine boil.'

Ma bus-sala laka-se: 'The origin rituals bubble.'

Having achieved this state of ritual heat, it is essential to return life to a condition of 'coolness'. This involves a set of calming rituals using coconut water and other plants to render conditions to a tranquil coolness. In ordinary life, intense argument produces a 'heated' state. Sermons, particularly those by an able preacher, are expected to reach a heated crescendo and then, with song and prayer, to taper off to a less intensive state. All such intensity must be controlled and carefully bounded; however, its existence is part of the pattern of life itself.

\section{Living in an oratorical culture}

One Rotenese botanic metaphor for sociality is that of a forest of trees whose branches continuously rub against each other (nula kekek//lasi nggio-nggio). On an island with relatively little forest cover, this metaphor reflects an image of the ideal society, which, as described in the Rotenese botanic idiom, is: 
Tema toe-ao lasin na: 'Intact like a thick wood.'

Teman losa don na: 'Intact for a long time.'

Ma tetu lelei nulan na: 'And in order like a dense forest.'

Tetun nduku nete na: 'Ordered for an age.'

The chaffing and rubbing of branches in this forest refer to the social interaction between individuals that is part and parcel of ongoing social life. A feature of this interaction is verbal interaction-a torrent of talk and argument that brings people together. The verb kekek, used to describe the 'rubbing' of branches, is also the verb 'to tease and annoy'.

In any opportunity to talk, there is much on show: the 'outer' semblance of the person and an intense inner sense of personal character. There are implicit rules of speaking: elders dominate assembled gatherings and men speak more than women, although older women can be quite forthcoming. But the younger generation among themselves are as talkative and argumentative as their elders. I have even encountered young children giving 'speeches' to one another in imitation of what they encounter daily.

In this elaborate talk, there is also considerable control. As Dutch travellers noted in the nineteenth century, everywhere on Rote there were local courts whose activities were the source of exuberant argument (see Kate 1894: 221). Each of the 18 domains on the island had a court as its focus. In most domains, disputes were the order of the day and were dealt with at various levels; lineage and clan lords and local elders were called up to hear a variety of disputes. Only a select few cases-the most intractablemade their way to the domain court.

Court cases were a regular function of life during my first period of fieldwork, as were a plethora of lesser local disputes. The disputes at Termanu's court, though often fiercely contested, were hedged by court procedures. When a case was eventually settled, often after several sittings, there occurred the provision of 'paku [nail] payments' to the court, which were intended to fix judgement in the case. These payments generally consisted of several bottles of gin that were drunk by all who were present, including the litigants.

Funerals are another regular occasion for disputes. Funerals are large social gatherings at which, formally and publicly, all a person's debts and ritual obligations to maternal relatives must be acquitted before burial can occur. (Formerly, when the court existed, members of the court and elders would convene, in ad hoc fashion during the funeral feast, to settle such matters.) 
At such gatherings, and indeed at many court cases, the satisfactory settlement is usually a verbal one. Ritual payments must follow strict verbal frames, which are grandiose labels that set out exchange payments in terms of rice fields, herds of water buffalo and quantities of gold-all of which must be fulfilled. The question is not about ritual payment since payment must be fulfilled, but rather about what will be accepted as the agreed on 'substitute' for the ritually designated label. In the end, after a great deal of argument, a chicken or goat may be given as a substitute for a buffalo and a relatively small amount of money provided in place of gold. In retrospect, however, only the grand ritual exchange payments tend to be remembered and the efforts that went into achieving these payments. ${ }^{5}$

In local disputes, there are fewer fixed procedures than at a court hearing and, as a consequence, disputes can often become quite heated. Rotenese have at their disposal a rich, robust scatological repertoire for mockery and abuse and they can resort to this whenever an argument escalates. ${ }^{6}$ This mockery language is called dede'ak a'ali-o'olek and, as Rotenese explain, it is explicitly intended to 'arouse anger' (nafofoa nasak). Significantly, it is also said 'to pierce the liver/heart' (natola boa-de'ek). Here a specific body part, the boa-de'ek, normally associated with the 'liver' (but sometimes also associated with the 'heart' as a physical organ and not as dalek) is identified as a target. The purpose is 'to wound' another.

Most expressions of abuse refer to parts of the body-a person's body or that of a parent. In particular, they refer to the arse or genitalia and link these body parts to qualities of condition, size and smell. Reference to the skull of a parent is also abusive. Reference can also be made to disabilities. Many expressions translate easily into English: moe-ao ('piss-self') or tei-ao ('shit-self'). My favourite is pake-tilak ('vagina-deaf'), although I am not sure whether it is applied to a man or a woman. Abuse can also be directed to a person by making comparison with animals, such as dii-dok kapa ('buffalo-eared') or mata bi'ik ('goat-eyes'). It is significant that all forms of

5 I have discussed the use of these verbal frames in a paper, "Chicken bones and buffalo sinews": Verbal frames and the organization of Rotinese mortuary performances' (Fox 1988). The persistence of these formulae gives continuity to social life_-or at least to the remembrance of social life-despite enormous change over centuries. Such frames allow the Rotenese to claim they continue to conduct themselves in the manner of their ancestors.

6 I have written at length on this mockery language in a paper entitled " I'll mock you to fine dust": Rotinese language of mockery, abuse, and cursing' (Fox 1992). The paper lists over 100 different expressions of abuse while indicating the formulae by which one might concoct many hundreds of other terms of abuse. 
abuse and mockery are directed to the body (ao) rather than to the name or to the 'hard name' (nade balakaik). Insults to the name are of a whole different order and produce an immediate response that may escalate as others who share that name become involved.

\section{The social control of violence}

Given the near daily occurrence of situations that could escalate, there is surprisingly little resort to acts of physical violence when arguing. A strong underlying belief among Rotenese is that, if one cannot win one's verbal argument and succumbs to a physical response, one has lost not only the argument itself but also self-respect, and is publicly shamed. In the only case I heard about where this occurred, the individual in question, who had been drinking at the time, became the source of hilarity for days afterwards.

Similarly, if a husband were to resort to violence and strike his wife, this would be grounds for immediate divorce. The wife is expected to return to her father's or brother's house and the husband, if he wants to regain his wife, must make 'coaxing' payments to her family, which can be the equivalent of the original bride-wealth.

One case to which I had access at all levels is a good illustration of what may happen. A wealthy noble was considering taking a second wife. His wife learned of his plans and asked for a divorce, which he refused. The wife then set out to stalk her husband's every move, particularly when he attended court. The wife sat at a short distance from the mat on which the elders were assembled and let fly a torrent of abuse at her husband, detailing, among a string of inadequacies, the dismal quality of his genitalia and other body parts. I was sitting at that court session and remember one elder turned to tell me that no man could bear such abuse. At the time, I happened to be meeting regularly with the father of the wife. He was well aware of what was happening and was planning with his son to hold the purification ceremony (songo aok) for his daughter as soon as the husband could take no more and finally struck her. The wife's verbal abuse of her husband went on for days-longer than anyone predicted-but, as soon as her husband struck her, she left, returned to her family household, had the proper ceremony for purification of her body performed and then waited for her husband to respond. Eventually, he came courting again and was forced to make substantial 'coaxing' payments to convince her to return. 
In broad perspective, much of Rotenese social life is about performance. Like rituals, the 'rubbing and chaffing' of social interaction generate a degree of heat that must be controlled and ultimately rendered cool again-if only to reignite another verbal performance.

Yet there are other dimensions to social life and, in particular, the serious quest for knowledge.

\section{Church and school: The quest for knowledge as a fundamental value}

An ideal of knowledge (lela) is paramount among the Rotenese. One of the highest compliments one can make is to describe an individual as a 'person of knowledge' (hataholi malelak). The designation has broad connotations. In traditional terms, it implies a command of ancestral knowledge, of the ancestral narratives of the origins of things and the genealogies of the domain. Significantly, it also indicates a personal capacity to understand how this knowledge relates to everyday life. It implies a wisdom, discernment and deep sagacity that comes with age, status and experience and pertains most pertinently to the senior-most elders.

In ritual language, knowledge (lela) is paired and contrasted with (ndolo), which is the knowledge of craft and technique. The quest for these two forms of knowledge (lelal ndolo) is one of the most frequently cited quests of the ancestors, in particular, in relation to the knowledge of Christianity, but also in relation to knowledge in general.

Christianity became established on Rote in the early part of the eighteenth century and, with Christianity, came schooling in Malay, particularly in the Malay Bible. The first Rotenese ruler to be baptised with his family, in 1729, almost immediately called up the Dutch East India Company to request that a Malay local school be established in his domain. Eventually, the Dutch East India Company granted this ruler from Thie a schoolmaster. The first school was founded in 1735 . Other domains immediately began clamouring for schools. By 1754, there were six Malay schools provided by the company in return for a set payment in agricultural produce, but, by 1765 , the local Rotenese educated in Malay took over the island's schooling system at the behest of the local rulers. This schooling system went through fits and starts. The first missionary on Rote in the early nineteenth century closed the local schools because he considered them 
an affront to Christianity, but they were almost immediately reopened and grew in numbers throughout that century. In 1855, a Dutch Government schools inspector visited Rote. In his report, he described the Rotenese as a 'studious, clever and intelligent people' and recommended that a government-financed school be established in each of the 18 domains of Rote (Buddingh 1859-61: Vol. III, p. 326; see Fox 1977: 92-112, 127-39).

By 1871 , an additional 16 'village' schools were opened on Rote and a new phase in Rotenese history had begun. In the early part of the nineteenth century, small groups of Rotenese had been moved to the area around Kupang to ring the Dutch settlement with strategically located populations who could serve as a buffer against marauding Timorese. By the end of the nineteenth century, a new migration of educated Rotenese began to take up coveted positions in the Dutch administration as clerks and schoolteachers and to join fellow Rotenese in the surrounding region. Schools on Rote were the launching pad for this migration.

At present, there are as many Rotenese living in Timor, particularly in the Kupang area, as there are on Rote. In its linkages to Timor, Rote has remained a relative bastion of tradition while continuing to export much of its population in search of modernity.

In the view of present-day Rotenese, the quest for Christianity was an active pursuit. According to contemporary narratives, three rulers from the western part of Rote journeyed to Batavia and there obtained both the knowledge of Christianity and the knowledge of distilling. By a play on words, the two are equated: Christianity brought the knowledge of Allah; the distilling of local lontar juice gave the Rotenese the knowledge of 'gin' (ala, from the Malay word arak). Christianity is a tree of knowledge, described in the liturgy by dual names: Tui Sodak ma Bau Molek ('The Tui-tree of Wellbeing and Bau-tree of Peace'). Lontar gin, on the other hand, is 'the water of words' that lubricates ceremonial gatherings and was once used, with colouring added, at Christian communion services.

\section{The place of thought in Rotenese discourse}

The Rotenese have a rich vocabulary for discussing processes of knowing, thinking, pondering and assessing. Many of the terms for thinking are themselves paired and they can best be grasped by contrast to one another. Thus, the most general term for thinking is af, which pairs with du'a. Afill 


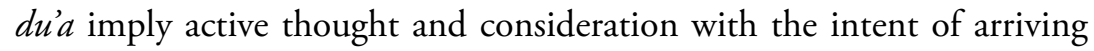
at some conclusion. By contrast, the pair of terms dodo//ndanda implies longer, more careful consideration. They convey the notion of a deliberate process in thinking. Often these verbs are accompanied by adverbs that imply both a time and a depth to the considerations involved in such thought. The verb lela in its active form, nalela, is paired with bubuluk. Nalelal/bubuluk indicate general processes of 'knowing'-whether this might be a knowledge of persons, places or things or a practical knowledge of how to do something. Crucial to all these ideas of thinking are ideas of remembering.

\section{Social memory and the nature of personhood}

Among the Rotenese there is a common and recurrent ritual refrain: Sadi mafa-ndendelek ma sadi masa-nenedak ('Only do remember and do continually keep in mind'). This expression is a strong admonition to preserve memories of the past and especially the memories of the relations commemorated in rituals. Implied in this admonition is an insistence on social memory.

Rituals are the markers that preserve such memories: they become 'memorials' and can, in some cases, result in physical forms of objects of remembrance-what Rotenese call koni-keakl/hate-haik.

The admonition 'to remember and to keep in mind' is used, most poignantly, in mortuary chants directed to the deceased, who is guided to leave the world of the living. Lamentations, known in Ringgou as boreu, are particularly powerful expressions of memory and its loss.

Addressed directly, the chanter conducts the deceased through all the stages that are believed to occur in the transformation from life to death while at the same time vividly invoking the personal life of the deceased. The chanter insists on remembering the little incidents in the personal life of the deceased while admonishing the deceased to try to remember them as well.

Here are excerpts from a lamentation (boreu) for an old woman by the master chanter Ande Ruy. This lamentation is in the dialect of Ringgou and extends for almost 200 lines. It consists of a string of images. I have selected a few segments that provide a mix of these images with the recurrent insistence on remembering. 
The chanter repeatedly asserts what he himself remembers, but he also urges the deceased to remember-even as the deceased separates from the living (sailing westward on her funeral boat and perahu), decomposes ('falling like an old coconut'//'withered like an areca nut') and becomes unable to remember what only the living continue remember.

In these excerpts, segment VII is significant but difficult to comprehend: the Rotenese believe that the recent dead return briefly for several nights after the funeral. They assume the form of a kind of insect and partake of the offerings of rice porridge set out on their behalf. In this manifestation, their capacity to remember is sadly diminished.

Besides 'remembering and keeping in mind', these few lines also portray other basic Rotenese notions of emotion and thought: loving//having affection (sue//lai), speaking and talking (dea-deal/kola-kola) and knowing and understanding (lela//rolu):

I

Ua ia tao lée boe

Ma nale ia tao lée, besa

De rina basa nusa ara boe

Ma basa iku ra boe, besa

Bei ro dudi no-nara

Ma ro tora tuke-nara

Fo au afa rene lolo, besa ei

Do ameda rara...

II

Mana-sue o nei

Ma mana-lai o nei,

Mata malua ia

Ma idu maka ledo ia

Te neuko su'i besi neu ko

Ma koe riti neu ko.

O besa, londa asa neu dulu

Ma ba pou neu laka.

He'e au we o neu ko

Tika mala balum lain,

Balu pao-ma lain

Ma hene mala tondam lain

Tonda ufa-ma lain ...
What fortune is this?

What fate is this, Grandmother?

There through all the domains

And all the lands, Grandmother

Still with many relatives

And with many kin

I do continue to remember,

Grandmother

Or steadily bear in mind ...

So loving

And so affectionate,

The eye of day is dawning now

The nose of the sun is shining now

But the coffin nails strike for you

And the coffin lock closes for you.

Oh Grandmother, drape cloth in the east

And wrap the cloth at the head.

We lament for you

Climb aboard your perahu

Aboard your sailing perahu

Mount aboard your boat

Aboard your sailing boat ... 
III

De au afarene lololo

Ma asa neda rara, besa.

Fo hida bei leo hatan

Ma data bei leo don

Ifa mala buna leo

Ma o’o mala soro mala leo ...

Nai lo a dale

Ma nai uma a dale

Ifa mara upu mara

Ma o'o mara soro mara...
I do continue to remember

And I do continue to keep in mind, oh Grandmother.

At a time long ago

At a time since past

You cradled the flowers of your clan

And you carried the descendants of your clan ...

Within the home

And within the house

Cradling your grandchildren

And carrying your descendants ...

\section{IV}

Neuko leko la fo mu

Ma pale uli fo mu

De neuko leko la Safu Muri

Ma pale uli Seba I'o.

De tule ta di'u dua so

Ma fali ta soro lele so ...

$\mathrm{V}$

Ela dea-dea, besa o

Ma ela ola-ola dei, besa 0.

Sadi rene mafa-rene

Te nai oe ma so

Ma sadi neda masa neda

Te nai dae ma so ...

$\mathrm{VI}$

Afa rene lololo

Ma ameda rara

Mata esa ko matan

Ma rolu esa ko rolu

Ma idu esa ko idu

De lela esa ko lela...
Now set sail to go

And turn your rudder to go

Set sail for Savu in the west

And turn your rudder to Seba at the tail.

Do not return, having turned your back

And do not come back, having turned round ...

Let's speak to one another, oh Grandmother

And let's talk to one another, oh Grandmother.

Only remember, do remember

Where your water once was

And only recall, do recall

Where your land once was...

I continually remember

And I constantly recall

Eye to eye

Knowing each other

Nose to nose

Understanding each other ... 
VII

Te neuko fati ara tao lada

Ma boro ara tao do

O tule di'u dua mai

Ma fali soro lele mai.

Te ma-mata bupu timu

Fo mahara bupu timu

Ma ma-idu fani lasi

Fo ma-dasi fani lasi...
But in the middle of the night

And late in the night

You can return, turning back

And come back, turning round.

With the eyes of a bumble bee

The voice of a bumble bee

And the nose of a honey bee

The sound of a honey bee ...

VIII

Ami mafarene lolo

Ma masaneda rara

Ua leo besak ua.

Ma nale besak nale.

Mama lasi leo no

Fo ono aom leo no

Ma mama latu leo pua

Fo refa aom leo pua.

Mita mai leo be a

Fo balaha leo be a

Ma ami bulu mai leo be a

Fo binesa leo be a...
We continually remember

And bear in mind

Fortune like the present fortune.

Fate like the present fate.

Mother old as a coconut

Your body falls like a coconut

And mother withered as an areca nut

Your body drops like an areca nut.

We will see what happens

What tomorrow will be

And we will learn what will be

What the day after next will be ...

For the Rotenese, memories constitute the social person and these precious memories are what dissolve and disappear when the body dies.

\section{Conclusion}

This chapter can, at best, be considered an initial exploration of the complexities of Rotenese expressions of thought and emotion. I have concentrated on what I consider to be key defining notions that are at the core of the Rotenese social person. To enhance my presentation, I have deliberately focused on the use of terms for thought and emotion in Rotenese ritual language. The intellectual and emotive power of Rotenese ritual language is at the core of Rotenese culture. In ritual language, terms are always paired and the remarkable pairings of terms for thought and emotions, I would argue, are revealing. 
For a comparative study of the expression of thought and the emotions among the Austronesians, the Rotenese case highlights recognisable, comparable particularities: inside versus outside, the eye as source and the focus of emotions, the linkage between fear and shame and the subtle associations of heat and coolness as emotional states. At this basic level, Rotenese shares an Austronesian emphasis on particular terms that link thought and the emotions to specific parts of the body, but the intellectual elaboration of these notions is distinctively Rotenese.

\section{References}

Barnes, Robert H. 1977. 'Mata in Austronesia'. Oceania XLVIII(4): 300-19. doi.org/10.1002/j.1834-4461.1977.tb01301.x.

Buddingh, S. A. 1859-61. Neerlands Oost-Indië. 3 vols. Rotterdam: $\mathrm{M}$ Wojt en Zonen.

Fox, James J. 1971. 'Sister's child as plant: Metaphors in an idiom of consanguinity'. In Rodney Needham (ed.) Rethinking Kinship and Marriage, pp. 219-52. London: Tavistock.

Fox, James J. 1977. Harvest of the Palm: Ecological change in eastern Indonesia. Cambridge, MA: Harvard University Press. doi.org/ 10.4159/harvard.9780674331884.

Fox, James J. 1988. “'Chicken bones and buffalo sinews”: Verbal frames and the organization of Rotinese mortuary performances'. In David S. Moyer and Henri J. M. Claessen (eds) Time Past, Time Present, Time Future: Essays in honour of P. E. de Josselin de Jong, pp. 178-94. Verhandelingen van het Koninklijk Instituut voor Taal-, Land- en Volkenkunde 131. Dordrecht: Foris Publications.

Fox, James J. 1992. "“I'll mock you to fine dust": Rotinese language of mockery, abuse, and cursing'. In Tom Dutton, Malcolm Ross and Darrell Tryon (eds) The Language Game: Papers in memory of Donald C. Laycock, pp. 581-8. Canberra: Pacific Linguistics.

Fox, James J. 2007. 'Traditional justice and the "court system" of the island of Roti'. The Asia Pacific Journal of Anthropology 8(1): 59-74. doi.org/10.1080/14442210601166665. 
EXPRESSIONS OF AUSTRONESIAN THOUGHT AND EMOTIONS

Kate, H. F. C. ten. 1894. 'Verslag eener reis in de Timorgroup en Polynesië [An account of a trip through the Timor group and Polynesia]'. Tijdschrift van den Koninklijk Nederlandsch Aardrijkkundig Genootschap (2nd series)11: 195-246; 333-90; 541-638; 659-700; 765-823. 
This text is taken from Expressions of Austronesian Thought and Emotions, edited by James J. Fox, published 2018 by ANU Press, The Australian National University, Canberra, Australia.

doi.org/10.22459/EATE.04.2018.05 